\title{
Detection of endometritis using uterine cytobrush and ultrasonography in mares
}

\author{
M.A. Rahawy ${ }^{1}$, A.G. Al-Haaik ${ }^{\circledR}$ and E.H. Lazim ${ }^{1}(\mathbb{C}$ \\ ${ }^{1}$ Department of Surgery and Theriogenology, ${ }^{2}$ Department of Anatomy, College of Veterinary Medicine, University of \\ Mosul, Mosul, Iraq
}

\begin{tabular}{l} 
Article information \\
\hline Article history: \\
Received December 18, 2020 \\
Accepted June 19, 2021 \\
Available online October 13, 2021 \\
\hline Keywords: \\
Mare \\
Endometritis \\
Cytobrushing \\
PMNs \\
Ultrasound \\
\hline Correspondence: \\
A.G. Al-Haaik \\
alhaaik_ag@uomsul.edu.iq
\end{tabular}

\begin{abstract}
The objective of this study was to detect the percentage of Polymorph nuclear cells (PMNs) from the uterine smears using the local manufactured uterine cytobrush instrument, and to determine the echogenicity the intrauterine fluid by Ultrasonography. Thirty (Arabian) repeat breeder mares were used. Animals were examined through rectal palpation and ultrasound. Mares were divided into 4 groups depending on the results of: 1) the amount of intrauterine fluid using ultrasound; 2) the endometrial samples were collected during estrus cycles, 3) the numbers of uterine epithelial cells and PMNs using locally manufactured cytobrush tool, 4) the number of lymphocytes. The results showed that the incidence of endometritis had significantly related to that age of the animals. The number of PMNs were significantly different between groups. The mean number of PMNs was $1.63 \pm 0.23,3.34 \pm 0.18,4.78 \pm 0.26$ and $5.26 \pm 0.46$ in $\mathrm{G} 1, \mathrm{G} 2, \mathrm{G} 3$ and $\mathrm{G} 4$, respectively. The echogenicity of the accumulated fluid in the endometrial lumen was significantly associated with the percentage of lymphocytes. The mean number of lymphocytes was $1.02 \pm 0.42$ and $1.84 \pm 0.37 \%$, in G3 and G4 respectively. This study concluded that the cytobrush technique is rapid, cheap, safe technique and easy to obtain samples from mare's uterus in the field. Consequently, Ultrasound and cytological techniques could be recommended for diagnosis of endometritis in mares.
\end{abstract}

DOI: $10.33899 /$ ijvs.2021.128858.1608, , CAuthors, 2022, College of Veterinary Medicine, University of Mosul.

This is an open access article under the CC BY 4.0 license (http://creativecommons.org/licenses/by/4.0/).

\section{Introduction}

Endometritis is regarded as an important disease in mares which lead to subfertility with reduced an economical benefit by about $15 \%$ (1). In terms of microbial factors, there is a great variance among microbes including induction of inflammation, epithelial adherence, resistance to phagocytosis, viscosity of secretions and the status of the uterine defense mechanism (2).

The major bacterial causes of endometritis in mares are E. coli and hemolytic streptococci from the vagina $(3,4)$. There are several methods have been used to diagnose endometritis in mares such as clinical examination; palpation per rectum; ultrasonography, vaginal examination, uterine culture, cytology, and endometrial biopsy (5). Endometritis in mare usually associated with accumulation of amount of fluid in the uterus (3). It has been reported that Mares with the presence of intrauterine fluids following inflammation had a shorter inter-ovulatory interval which has been observed after premature regression of the corpus luteum which results in the premature release of prostaglandins $(6,7)$.

In terms of echogenicity, it has been reported that the presence of hyper echoic particles in the uterine lumen are associated with endometritis in mares. The diameter of this fluid area acts as an important method to distinguish between uterine secretions and inflammatory fluids or exudates (7).

In order to distinguish between the volume and echogenicity of the different types of fluids accumulation in 
the uterine lumen is based on a system of grades (related to the amount of debris or inflammatory cells), which could be link to the fertility of the mare (6). On a transverse section of a filled uterine horn with secretions, the folds of the endometrium occasionally form projecting bulges into the lumen with wavy or scalloped line which separates the secretions and the uterine wall. The 6-8 folds of the endometrial mucosa that normally present in the mare are quite often identified. Secretions lead to the dilation of the uterine cavity resulting in the penetration between the folds and separating them, whereas the folds are closely adjoining when the uterus is empty $(6,8)$.

Cytological and bacteriological investigations have been used for the diagnosis of the severity of endometritis (9). It should be noted that a positive bacterial culture may not be associated with endometritis and reduced fertility in mare $(10,11)$.

The cytological examination is regarded as a valuable diagnostic tool with high sensitivity compared to the bacteriological investigation. In addition, cytobrush has been recognized as less aggressive methods by which endometritis can be gauged. Endometrial cytology is used as a fast technique for detection of the degree of endometritis in the mare by calculation Polymorph nuclear cells PMNs (12).

Furthermore, various methods have been used to classify cytological grades; such as detection the number of PMNs as a percentage of all cells noticed in a smear and record actual numbers of cells show per microscopic field (13). The advantage of cytology is the ability to obtain results early with low cost and rapid availability of results, while bacteriological examination takes 2-3 days until to get the results $(10,12-14)$. There are several methods used to obtain samples form the uterus including cytology brushes and uterine lavage (15). Previous studies have been recorded that cytology brushes technique is better for collecting samples than that collected with cotton swabs (10). The percentage of neutrophils to endometrial epithelial cells $0.5 \%$ to $2.5 \%$ was used by some authors as an indicator of inflammation $(10,11,16,17)$. Others count the number of neutrophils observed in several 1000x fields $(11,12,18)$. The primary aim of the present study was to detect of the numbers of PMNs and lymphocytes percentage in the uterine smears by the locally manufactured uterine cytobrush instrument and echogenicity of the intrauterine fluid by Ultrasonography for diagnosis of endometritis in Mares.

\section{Materials and methods}

\section{Animals}

Current study was carried out on a total of 30 repeat breeder (Arabian) multiparous mares without foals. Animals were obtained from Teaching Veterinary Clinical Service at the College of Veterinary Medicine, Mosul
University and Nineveh Equestrian Club in Mosul, Iraq. Animals were aged from 6-18 years old; they were mated by stallion of known fertility. Mares with history of reproductive failure during the year 2018- 2019 where they have been bred three times unsuccessfully in the current breeding season, during the period between March and July were used.

\section{Clinical examination}

All gynecological examinations and sampling were carried out by hands with stock-restrained mares. The dominant ovarian follicle $30 \mathrm{~mm}$ in diameter had been recognized by gynecological examinations including palpation per rectum and ultrasonography in the Mares.

\section{Ultrasonography examination}

The mare's reproductive tract was examined via two types of Trans-rectal ultrasonography first real time Bmode scanner, Medison CO., Korea and second Mindray, DP-6900Vet, China with probe $7.5 \mathrm{MHz}$ trans rectal transducer) for the evaluation of mature ovarian follicle, presence or absence of uterine fluid and for determination of uterine wall thickness (19). Ultrasound scanning used to quantify the mean gray value which used as an indicator of the changes in the echogenicity of the endometrium and the intra-uterine fluid and these changes were classified into: Small amount of an intrauterine anechoic fluid, Moderate intrauterine slightly echogenic fluid, High intrauterine echogenic fluid, Huge amounts of an intrauterine echogenic fluid (8). Mares were grouped according to ultrasound scanning only to identify the amount of intra uterine fluid into: Group $1 \quad(\mathrm{G} 1 ; \mathrm{n}=5)$ had small amount of an intrauterine anechoic fluid. Group $2(\mathrm{G} 2 ; \mathrm{n}=8)$ had moderate intrauterine slightly echogenic fluid. Group 3 (G3; n=13) had high intrauterine echogenic fluid. Group 4 $(\mathrm{G} 4 ; \mathrm{n}=4)$ were characterized by the presence of huge amounts of an intrauterine echogenic fluid with thickness of uterine wall.

\section{Sample collection}

Endometrial sample were collected at the studs' appearance immediately as the mares were behaviorally in estrus, the mare tail was wrapped with band, the vulva and perianal area were washed with a non-residual solution and cleaned three times with water to remove all external debris and dried by towel a paper (12). Cytobrush tool was locally manufactured from stainless steel plunger without a knob handle; (artificial insemination gun) and connected with new mascara brush, and then was covered with a thin sheath of aluminum (exterior tube). The brush tool was covered with glove to prevent vaginal contamination and then sterilized by autoclave before collection of samples. The endometrial cytology (EC) samples were collected, using a new cytobrush tool with application of small amount of sterile lubricant. This new tool was introduced 
manually through the vulva, vagina, and cervix and advanced into the uterine body and then the glove was pierced to expose the tool to collect the sample.

At this stage the aluminum sheath was retracted far enough to expose the cytobrush to collect endometrial samples by rotating the tool in a circular direction in contact with the uterine wall to collect enough cells within few minutes. Finally, after the tool was removed from the uterus gently endometrial cytology smears were prepared immediately by gentle rolling the cytobrush on a pair of a new glass microscope slide for each mare. Smears were airdried on a warming tray cytobrushing and for a few minutes, then smears were fixed with methyl alcohol and then stained rapidly by Leishman's stain, Stained smears were air dried and mounted $(9,18)$ (Figure 1).

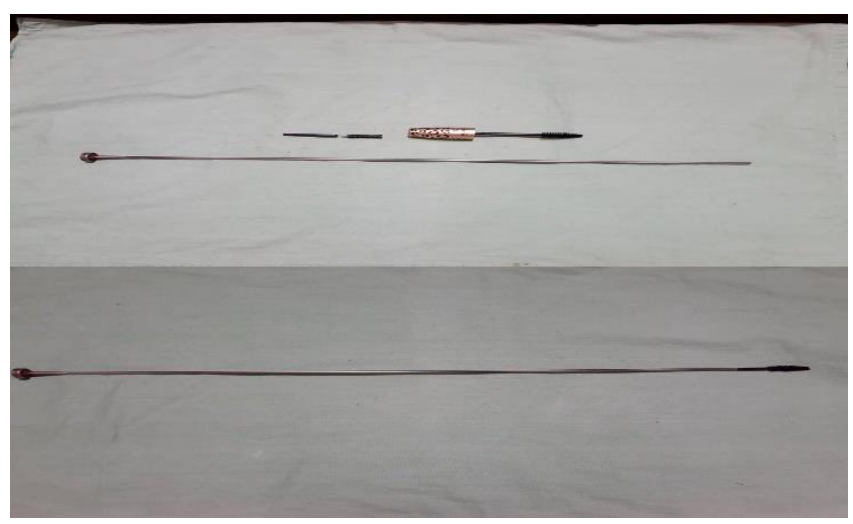

Figure 1: New cytobrush tool was locally manufactured from stainless steel plunger without a knob handle; (artificial insemination gun) adhered with new mascara brush.

\section{Uterine cytology}

Cytological smears were examined using light microscope at 40x field lens to check the presence of uterine epithelial cells and Polymorph nuclear cells (PMNs). Then high-power field 100x (HPF) was used to count the PMNs and epithelial cells from each smears. The average number of PMNs / HPF (high power field) was quantified from at least ten fields in multiple areas of each smear. The degree of the inflammation was evaluated at high-power field 100x and graded (12) into: Normal (no PMNs to rare PMNs / HPF); Mild inflammation (1-2\% PMNs / HPF); Moderate inflammation (3-5\% PMNs / HPF); Severe inflammation (>5\% PMNs / HPF. In addition, some cytobrush samples contained a moderate to high amounts of debris that is presumed to be cellular materials from broken cells, extracellular bacteria or dead sperms. The diagnostic value of cell morphology was categorized as follows: The neutrophil index was considered according to Card, 2005 which was then calculated depending on the numbers of the two cell types. Smears with over $0.5 \%$ PMNs were classified as positive. The number of red blood cells per high-power field was assessed semi quantitatively and classified as none, few, numerous and massive numbers $(10,12)$.

\section{Statistical analysis}

Data information are presented as mean \pm standard error. The recorded data of Statistical analyzed using Chisquare test with $\mathrm{P}$ value was significant at $\mathrm{P}<0.05$ by using Statistical Analysis program (SPSS Ver. 16).

\section{Results}

The results of this study showed that the incidence rate of endometritis in mare was $16.66,26.66,43.33$ and $13.33 \%$ in G1, G2, G3 and G4, respectively (Table 1). The degree of endometritis was significantly associated with the age at 10-14 years of animals (Table 1). Ultrasonography outcome form inflamed uterus revealed that the presence of an echogenic accumulated intra-uterine fluid considered as an indicator of clinical inflammation of the uterine wall. Grading of the uterine inflammatory fluid echo pattern was performed by gray scale echogenicity, which showed that the mean uterine fluid echogenicity was proportioned with increased thickness of endometrial wall in cases of endometritis grade G1, G2, G3and G4, respectively (Table 1) (Figures 2 and 3). Cytological examination revealed that the mean number of neutrophil was significantly different between grades (Table 1). The mean number of neutrophil were $1.63 \pm 0.23,3.34 \pm 0.18,4.78 \pm 0.26$ and $5.26 \pm 0.46$ per high-power field (HPF), in G1, G2, G3 and G4, respectively (Table 1).

Table 1: Descriptive and endometrial cytological findings in Arabian mares associated with endometritis

\begin{tabular}{lcccc}
\hline Groups & Group 1 & Group 2 & Group 3 & Group 4 \\
\hline Number of mare & 5 & 8 & 13 & 4 \\
Age of mare (year) & $6.9 \pm 0.17^{\mathrm{a}}$ & $10.32 \pm 0.29^{\mathrm{b}}$ & $13.47 \pm 0.11^{\mathrm{c}}$ & $16.74 \pm 0.23^{\mathrm{d}}$ \\
Incidence of endometritis & $16.66 \%$ & $26.66 \%$ & $43.33 \%$ & $13.33 \%$ \\
PMNS cells /HPF & $1.63 \pm 0.23^{\mathrm{a}}$ & $3.34 \pm 0.18^{\mathrm{b}}$ & $4.78 \pm 0.26^{\mathrm{c}}$ & $5.26 \pm 0.46^{\mathrm{c}}$ \\
Lymphocyte cells /HPF & $0.00 \pm 0.00^{\mathrm{a}}$ & $0.00 \pm 0.00^{\mathrm{a}}$ & $1.02 \pm 0.42^{\mathrm{b}}$ & $1.84 \pm 0.37^{\mathrm{c}}$ \\
\hline
\end{tabular}

Values with different superscripts within the same row were significantly different at $\mathrm{P}<0.05$. HPF: high-power field. 

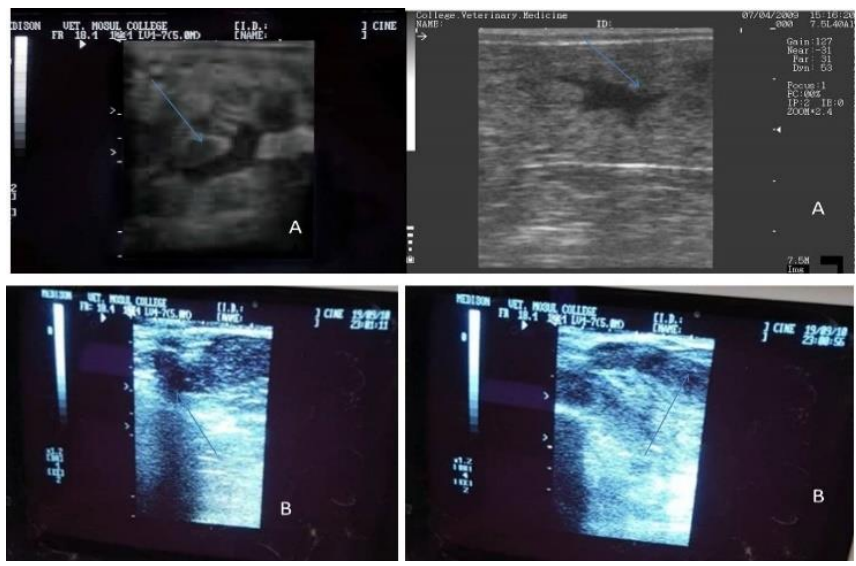

Figure 2: Ultrasound images for the Mares enrolled in this work. The image (A) shows a small amount of an intrauterine an echoic fluid with the folds of the endometrium bulges projecting into the lumen. The image (B) shows moderate amount of an intrauterine an echoic fluid of indicating endometritis in the mares.
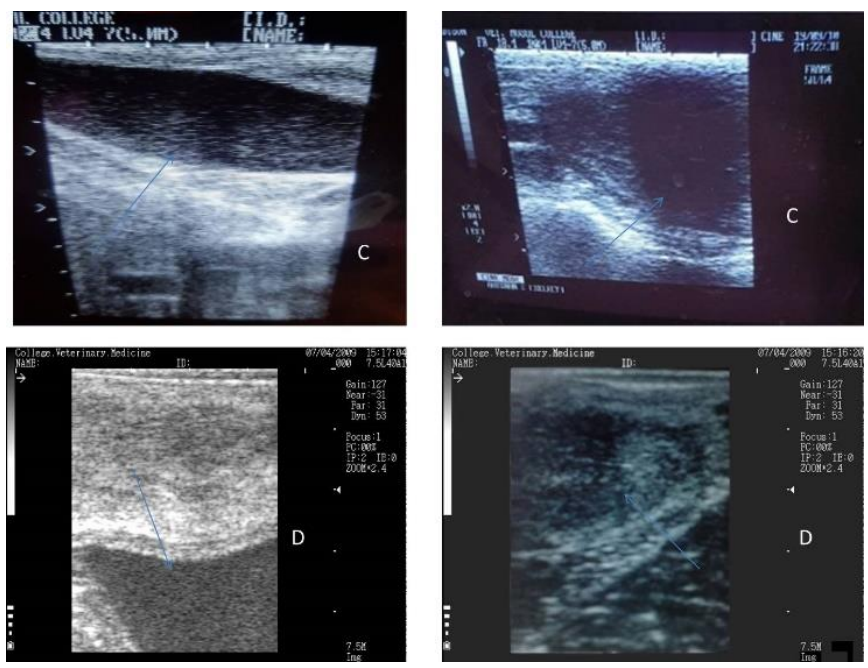

Figure 3: Ultrasound images for the Mares enrolled in this work. The image $(\mathrm{C})$ with high amount of an intrauterine an echoic fluid, while image (D) showed an accumulation of high amounts of an intrauterine huge echogenic fluid with thickness of uterine wall of the indicating endometritis in the mares.

In all examined samples, there was an obvious increase in the number of neutrophils or more than one neutrophil was observed per field, at the same time, neutrophils were observed in the vast majority of fields (Figure 4). There was also one sample taken by swab revealed a few small areas containing increased number of neutrophils, the results of the cytological evaluation were reported in (Table 1) (Figures 4 and 5). The results from cytological examination showed that there were not lymphocytes noticed in the G1and G2 (Figure
3). Group 3 had low number of lymphocytes at average of 01 lymphocytes/HPF (Figure 3). It should be noted that the number of lymphocytes was significantly different between G3 and G4 (Table 1). Group 4 had highest number of lymphocytes which was association with the high number of neutrophil cells.
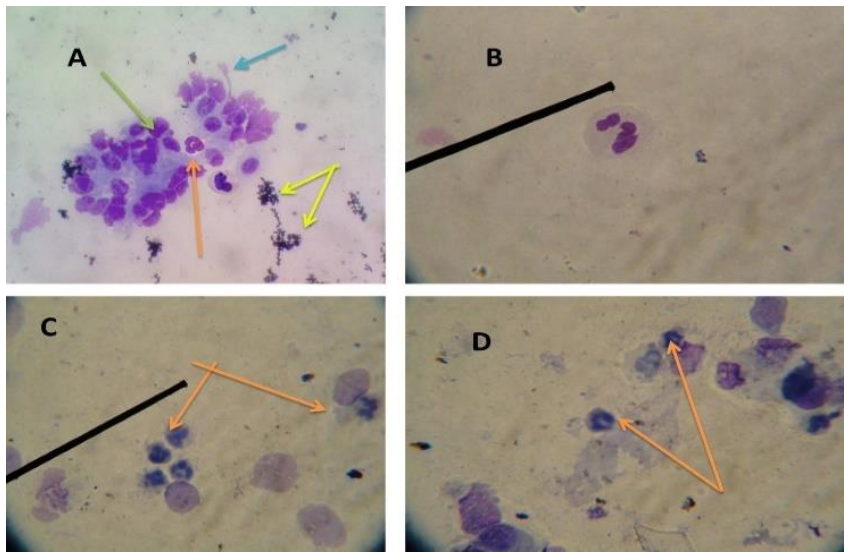

Figure 4: Photomicrographs of equine endometrial cytology smear. Smear of group 2 (A) shows PMN cells (orangs' arrow), columnar epithelial cells (green arrow), bacterial colony (yellow arrow) and spermatozoa (blue arrow) while smear of group 1 (B) shows PMN cell, the smear of group 3 (C) illustrates show high PMN cells, while the smear of Group 2 (D) shows PMN cells indicating features endometritis in the mares stained by Leishman's stain (100 $\mathrm{x})$.
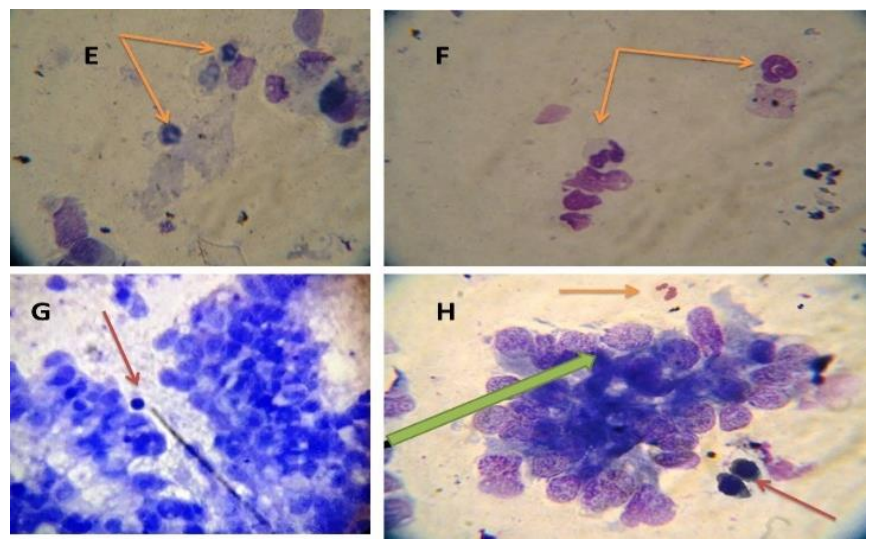

Figure 5: Photomicrographs of equine endometrial cytology smears. The smears of group 2 (E) show PMN cells (orangs' arrow), while that of group $4(\mathrm{G})$ show PMN cells (orangs' arrow), epithelial cells with lymphocyte cell (red arrow), The smears of group $4(\mathrm{H})$ show PMN cells (orangs' arrow), epithelial cells (green arrow) with lymphocyte cells (red arrow) indicating presence of the endometritis in the Mares stained by Leishman's stain, (100 x). 


\section{Discussion}

Endometritis is regarded an important disease and causes infertility in mares, which comes as third in rank following colic and respiratory tract diseases in equine (20). The present study reported that there was a significant relationship between age of animals and the incidence of endometritis, due to poor uterine contraction after natural service in older mares recorded highest rate of severe grade of endometritis. In accordance to (21) reported that the incidence of endometritis increased with increased parity of animals (22). Previous studies mentioned that reproductive performance and fertility in mares is increased at age 12-13 years $(23,24)$. The current study showed intrauterine fluids accumulate rarely at different periods at estrous cycle and causes infertility in mares; however, accumulation of uterine fluid has been reported in mares with endometritis at estrous cycle. The results of this study were in agreement with (22), they suggested that a history of infertility associated with uterine fluid accumulation during the reproductive period can be considered the most useful practical indicator of a sensitive mare to endometritis by clinical examination.

The study reported that the accumulation of uterine fluid echogenicity $(8,25)$ who graded the intra-luminal uterine fluid (Graded I to IV) according to the degree of echogenicity i.e. the more echoic the fluid, the more likely the fluid is contaminated with debris including white blood cells. The results founded that the amount of intrauterine fluid accumulated was related with the grades of endometritis and this in agreement with (20) who reported that the existence of $>2 \mathrm{~cm}$ depth of fluid during estrus was considered as a predictor of susceptibility the uterus to get infection. However, small volume $(<2 \mathrm{~cm})$ of intrauterine fluid during estrus which didn't have an effect on pregnancy rate. Furthermore, $(20,21)$ stated that the presence of large volume (1-3 cm or greater) of anechoic fluid during estrus or immediate post-ovulation period could have negative impact on fertility. All sampling methods were achieved by the same operator; the manufactured brush technique by cytobrush tool recorded the highest quality of samples and was considered as an easy and quick method for collection of samples. In agreement with previous study (8) who using a human uterine cytobrush inserted into an artificial insemination gun. Therefore, the diagnostic sample by uterine cytobrush tool that is cheap and performs rapidly (24). A recent research showed that a value of $\leq 1$ PMNs $1400 \times$ field regarded normal mares as routine cytological evaluation (25). The endometrial cytology used as a good diagnostic indicator for endometritis in mares (12). Results presented in this study showed that the cytological examination of mares diagnosed to have different grades of endometritis were positive in all mares. The current study showed that there was a relationship between number of neutrophils (PMNs) /HPF and the grades of endometritis. These results were agreed with $(13,18)$ they reported that the number of neutrophils increased with severity of endometritis. The same studies reported that cytological smears with less than 1 poly morph nuclear cells (PMNs) /hpf regarded as normal; mild uterine inflammation often is indicated when smears have 1-2 PMN/ HPF; while 3-4 PMN/ HPF and 5-6 PMN/ HPF refer to moderate and sever inflammation, respectively with presence of microbial organisms by using of a guarded uterine brush. These findings suggested that cytological smears collected from endometritis mares contain large amounts of debris and may contain inflammatory cells. This debris may denote degenerated neutrophils, sloughed epithelial cells, sperms, and inflammatory residues. Smears with large quantities of debris were recorded as non-inflammatory if there were $<0.5$ neutrophils/field. Anaerobic bacteria may have domicile in the uterine lumen and were recognized by endometrial cytological samples $(14,26)$. It has been suggested that susceptibility to cytological evaluation for uterine infection associated with an impaired local uterine chronic reaction; lymphocytes are frequently accompanied by PMNs. It has been documented that chronic endometritis associated with lymphangiectasia (secondary to vascular degeneration), resulting in impaired cervical drainage, and loss of epithelium, excessive exudate and epithelial hyperplasia in uterine mares (18). Nielsen (10) considered that the presence of PMNs infiltration of the luminal epithelium regarded as a good indicator for endometritis in mares. Interestingly, in both Ultrasound and cytological technique could have a significant value associated with percentage of PMNs.

\section{Conclusions}

This study concluded that the cytobrush technique is rapid, cheap, safe technique and easy to obtain samples from mare's uterus in the field. Consequently, Ultrasound and cytological techniques could be recommended for diagnosis of endometritis in mares.

\section{Acknowledgement}

The authors thanks University of Mosul, College of Veterinary Medicine to support this work.

\section{Conflict of interest}

Authors declared that there is no conflict of interests.

\section{References}

1. Zent WW, Troedsson MHT, Xue JL. Post breeding uterine fluid accumulation in a normal population of thoroughbred mares: A field study. Am Ass Equine Pract. 1998;44:64-65. [available at]

2. Causey R C. Making sense of equine uterine infections: the many faces of physical clearance. Vet J. 2006;172:405-421. DOI: 10.1016.08.005

3. Klein C, Ennen S, Huchzermeyer S, Weiss R, Wehrend A. Analysis of the barrier functions of vulvovaginal fold and cervix to ascending 
bacterial contamination of the mare's reproductive tract. Tierarzt Prax. 2009;113-117. [available at]

4. Al-Abidy HF. Isolation and identification of pathogenic bacteria from genital tract of the Arabian mares affected with genital tract infection and antimicrobial sensitivity. Iraqi J Vet Sci. 2010;24(2):143-148 DOI: 10.33899/ijvs.2010.5607

5. Defontis M, Vaillancourt D, Grand FX. Comparison of three methods of sampling for endometrial cytology in the mare. Preliminary study. Tierarzt Prax. 2011;39(3):171-5. DOI: 10.1055/s-0038-1624633

6. Kahn W. Ultrasound Diagnosis in the Mare. Atlas of echographic diagnoses. Maloine. 1994;11-82. DOI: 10.5829/idosi.gv.2017.586.589

7. Al-Wataar BD, Abdullah RM, Omer YA. Diagnosis of pregnancy and pathological conditions in the genital system of small ruminants by ultrasonography. Iraqi J Vet Sci. 2016;30(1):9-13. DOI: $\underline{10.33899 / \text { ijvs.2016.119165 }}$

8. Kouider ZE, Benallou B, Houari H. Ultrasonographic and cytological diagnosis of endometritis in the mare. Glob Vet. 2017;19(4):586-589. DOI: $10.5829 /$ idosi.gv.2017.586.589

9. Walter J, Wehrend A. Exfoliative endometrial cytology as a diagnostic aid in the gynecological examination of broodmares. Pferdeheilk. 2007;23:481-488. DOI: 10.1055/s-0038-1623830

10. Nielsen JM. Endometritis in the mare: A diagnostic study comparing cultures from swab and biopsy. Theriogenol. 2005;64:510-518. DOI: 10.1016/j.theriogenology.2005.05.034

11. LeBlanc MM, Magsig J, Stromberg AJ. Use of a low volume uterine flush for diagnosing endometritis in chronically infertile mares. Theriogenol. 2007;68:403-412. DOI: 10.1016/j..2007.04.038

12. Rahawy MA. Study on the post-partum disorders and their relationship with the reproductive performance in Iraqi cow-buffaloes. Iraqi J Vet Sci. 2021;35(2):313-317. DOI: 10.33899/ijvs.2020.126771.1387

13. Purswell BJ, Ley W, Sriranganathan N, Bowen JM. Aerobic and anaerobic bacterial flora in the postpartum mare. J Equine Vet Sci. 1989;9:141-144. DOI: $10.1016 /$ S0737-0806(89)80020-6

14. Card C. Post-breeding inflammation and endometrial cytology in mares. Theriogenol. 2005;64:580-588. DOI: 10.1016/j.t.2005.05.041

15. Kozdrowski R, Gumienna J, Sikora M, Andrzejewski K, Nowak M. Comparison of the cytology brush and cotton swab in the cytological evaluation of the endometrium in mares with regard to fertility. $\mathrm{J}$ Equine Vet Sci. 2013;33:1008-1011. DOI: 10.1016/j.jevs.2013.03.003

16. Ball BA, Shin SJ, Patten VH, Lein DH, Woods GL. Use of a low volume uterine flush for microbiologic and cytological examination of the mare's endometrium. Theriogenol. 1988;29:1269-1283. DOI: 10.1016/0093-691X(88)90007-6

17. Overbeck W, Witte TS, Heuwieser W. Comparison of three diagnostic methods to identify subclinical endometritis in mares. Theriogenol. 2011;75:1311-1318. DOI: 10.1016/j.theriogenology.2010.12.002

18. Walter J, Neuberg KP, Failing K, Wehrend A. Cytological diagnosis of endometritis in the mare: investigations of sampling techniques and relation to bacteriological results. Anim Repro Sci. 2012;132:178-186. DOI: $10.1016 / j . .2012 .05 .012$

19. Cocchia N, Paciello O, Auletta L. Comparison of the cytobrush, cotton swab, and low-volume uterine flush techniques to evaluate endometrial cytology for diagnosing endometritis in chronically infertile mares. Theriogenol. 2012;77:89-98. DOI: 10.1016/j..2011.07.020

20. Bohn AA, Ferris RA, McCue PM. Comparison of equine endometrial cytology samples collected with uterine swab, uterine brush, and lowvolume lavage from healthy mares. Vet Clin Pathol. 2014;43(4):594600 DOI: $10.1111 / \mathrm{vcp} .12194$

21. Al-Sa'aidi JA, Al-Charak AH. Ovarian morphometric evolution in two consecutive estrous cycles of female rats treated with steroid-free bovine follicular fluid antiserum. Iraqi J Vet Sci. 2020;34(2):265-271. DOI: $10.33899 /$ ijvs.2019.125925.1187

22. Traub-Dargatz JL, Galman MD, Voss JL. Medical problem of adult horses, as ranked by equine practitioners. J Am Vet Med Asso. 1991;198:1745-1747. [available at]
23. Allen WR, Brown L, Wright M, Wilsher S. Reproductive efficiency of flat race and national hunt thoroughbred mares and stallions in England. Equine Vet J. 2007;39:438-445. DOI: 10.2746/042516407X1737581

24. Barbary HA, Abo-ghonema II, El-Bawab I E, Fadel M S. Diagnosis and treatment of bacterial endometritis in Arabian mares. Alexandria J Vet Sci. 2016;49(2):116-125. DOI: 10.5455/ajvs.211432

25. Canisso IF, Segabinazzi LG, Fedorka CE. Persistent breeding-induced endometritis in mares a multifaceted challenge: From clinical aspects to immuno pathogenesis and pathobiology. Int J Mol Sci. 2020;2:1432. DOI: $10.3390 /$ ijms 21041432

26. Ferris RA. Endometritis: Diagnostic tools for infectious endometritis. Vet Clin North Am Equine Pract. 2016;32: 481-498. DOI: $\underline{10.1016 / j . c v e q .2016 .08 .001}$

\section{الكثف عن التهاب بطانة الرحم باستخدام البرش

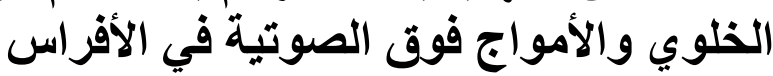

\author{
محمد عبدالاله رحاوي'، عمار غاتم الحائك`و إيمان حياوي لازم'

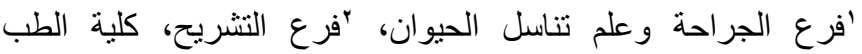

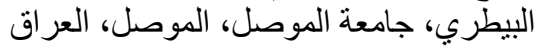 \\ الخلاصة
}

هدفت هذه الدراسة إلى الكثف عن نسبة الخلايا متعددة النواة في

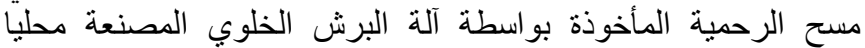
وتحديد صدويه السوائل داخل الرحم بتقنية الأمواج فوق الرية الصنية الصوتية

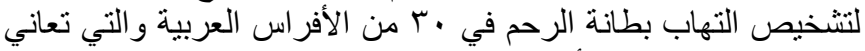

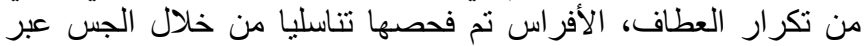
المستقيم وبالأمواج فوق الصوتية. قسمت الأفراس إلى الصى أربعة مجاميع

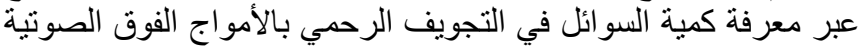

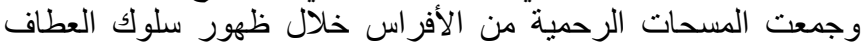

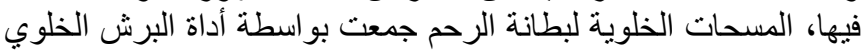

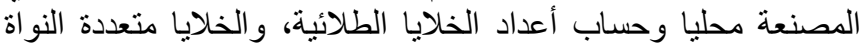

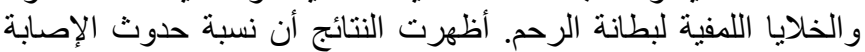

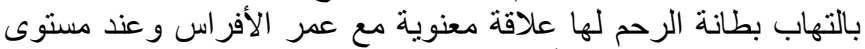

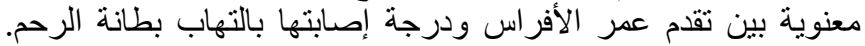

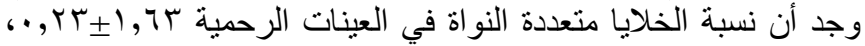
ع

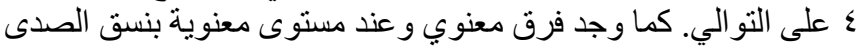

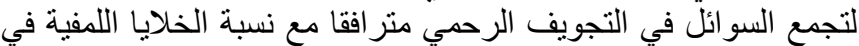

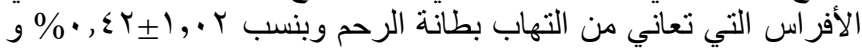
ع أن طريقة البرش الخلوي من الطرق السريعة الرخيصة التكاليف، امنه فئه

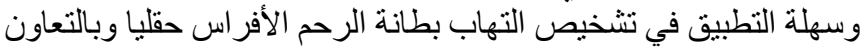
مع مدى صدوية السوائل داخل تجويف الرحمي باستخدام تقنية الأمواج فوق الصوتية، ونوصي باستخدام الطريقتين لتشخيص التهاب بطانة

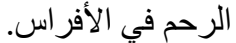

